\title{
Kajian Penggunaan Antibiotik pada Neonatus Intensive Care Unit di Sebuah Rumah Sakit Pemerintah di Surabaya
}

\author{
Felix Hidayat ${ }^{1}$, Adji P. Setiadi ${ }^{1,2}$, Eko Setiawan ${ }^{1,2}$ \\ ${ }^{1}$ Departemen Farmasi Klinis dan Komunitas, Fakultas Farmasi, Universitas Surabaya, \\ Surabaya, Indonesia, ${ }^{2}$ Pusat Informasi Obat dan Layanan Kefarmasian (PIOLK), Fakultas \\ Farmasi, Universitas Surabaya, Surabaya, Indonesia
}

\begin{abstract}
Abstrak
Penggunaan antibiotik menjadi salah satu terapi yang banyak diberikan pada bayi di Neonatal Intensive Care Unit (NICU). Penelitian ini ditujukan untuk mengetahui profil dan mengkaji biaya, ketepatan dan ketercampuran atau kompatibilitas penggunaan antibiotik pada pasien di NICU salah satu rumah sakit pemerintah di Surabaya dalam kurun waktu November-Desember 2015. Penelitian ini merupakan penelitian potong lintang yang dilakukan secara prospektif dengan memanfaatkan data rekam medis sebagai sumber data utama. Seluruh informasi yang diperoleh dari pasien NICU yang menggunakan antibiotik dan masuk dalam kriteria inklusi dan eksklusi dianalisis secara deskriptif. Total 32 orang pasien dilibatkan dalam penelitian ini. Penggunaan antibiotik terdiri dari 25 kali penggunaan antibiotik tunggal dan 14 kali penggunaan antibiotik kombinasi. Ampisilin merupakan antibiotik tunggal yang paling banyak digunakan, sedangkan penggunaan antibiotik kombinasi terbanyak adalah penggunaan kombinasi ampisilin dan gentamisin. Dari total seluruh pasien, hanya terdapat 13 pasien dengan diagnosis infeksi dan hanya 2 pasien $(15,38 \%)$ yang mendapat terapi antibiotik yang tepat. Proses pergantian terapi didominasi oleh proses de-eskalasi yaitu sebesar 44,44\%. Berdasarkan analisis kompatibilitas, terdapat banyak pencampuran sediaan antibiotik intravena yang tidak dapat diklasifikasikan compatible atau not compatible akibat tidak tersedianya informasi terkait kompatibilitasnya. Biaya penggunaan antibiotik yang harus dikeluarkan pasien rata-rata sebesar Rp265.252,00 ( $\min -\max =\mathrm{Rp} 16.100,00$ s.d. Rp2.091.590,00). Ketepatan penggunaan antibiotik di ruang NICU perlu ditingkatkan sebagai upaya untuk meminimalkan risiko dampak negatif khususnya peningkatan biaya dan risiko resistensi.
\end{abstract}

Kata kunci: Biaya antibiotik, kajian penggunaan antibiotik, kompatibilitas, neonatal intensive care unit

\section{Antibiotics Utilization Review in a Neonate Intensive Care Unit of a Public Hospital in Surabaya}

\begin{abstract}
Antibiotic is frequently used in the Neonatal Intensive Care Unit (NICU). The aim of this study was to identify the usage pattern and to review the cost, appropriateness, and compatibility of antibiotics given to the patients in the NICU of one public hospital in Surabaya during November to December 2015. This was a cross-sectional study using medical record as the main source of the data. All information about eligible patients receiving antibiotics in the NICU was analysed descriptively. A total of 32 patients was involved in this study. The antibiotics utilization profile consisted of 25 single and 14 combination therapy. Ampicillin and ampicillin-gentamycin were found as the most frequently used in the single and combination therapy, consecutively. From all patients received antibiotics, 13 patients had confirmed with infections problem and only 2 patients $(15.38 \%)$ received appropriate antibiotics therapy. From all therapeutic modification made, $44.44 \%$ was de-escalation. According to the compatibility analysis, lots of antibiotic intravenous admixtures in this research could not be clearly identified as compatible or not compatible because no information was available. The average cost of antibiotics per patient was IDR 265,252 (range IDR 16,100 to IDR 2,091,500). There is a need to optimize the use of antibiotics in the NICU in order to minimize the risk of adverse outcomes especially the increased cost and risk of resistance.
\end{abstract}

Keywords: Antibiotics utilization review, compatibility, cost of antibiotics, neonatal intensive care unit

Korespondensi: Eko Setiawan, M.Sc., Apt., Pusat Informasi Obat dan Layanan Kefarmasian (PIOLK), Fakultas Farmasi, Universitas Surabaya, Surabaya, Jawa Timur 60923, Indonesia, email: ekosetiawan.apt@gmail.com Naskah diterima: 11 Juni 2018, Diterima untuk diterbitkan: 18 Februari 2019, Diterbitkan: 1 Maret 2019 


\section{Pendahuluan}

Kematian pada bayi dan anak-anak dapat disebabkan oleh berbagai hal, dan salah satu penyebab terbesar adalah infeksi. ${ }^{1-3}$ Sebuah penelitian yang dilakukan di berbagai negara di dunia menunjukkan pneumonia menjadi penyebab kematian terbesar kedua pada bayi dan anak-anak yang berusia di bawah usia 5 tahun. $^{2}$ Penelitian lain yang dilakukan di Brazil juga menunjukkan besarnya kematian yang disebabkan oleh infeksi pada anak dalam hal ini adalah bayi. Dalam penelitian tersebut dinyatakan bahwa sebanyak 229 dari total 745 kematian bayi yang dirawat di Neonatal Intensive Care Unit (NICU) adalah disebabkan oleh sepsis. ${ }^{3}$ Salah satu faktor yang dapat meningkatkan risiko kematian pada anak dan bayi adalah penggunaan antibiotik yang tidak tepat, yang dapat berupa pemilihan jenis yang salah atau pengaturan dosis regimen yang tidak tepat. ${ }^{4}$

Bayi bukan merupakan orang dewasa dalam ukuran kecil karena fisiologis bayi memiliki banyak perbedaan dibandingkan dengan orang yang telah dewasa. Beberapa perbedaan yang dapat dijumpai antara bayi dan orang dewasa antara lain: 1) fungsi organ untuk ekskresi, yaitu ginjal dan hepar, belum sempurna; 2) komposisi cairan tubuh pada bayi per kg berat badan lebih besar jika dibandingkan dengan orang dewasa; 3) jumlah protein, khususnya albumin, belum sebanyak orang dewasa., Salah satu dampak dari perbedaan tersebut yaitu adanya perbedaan profil farmakokinetik (pharmacokinetic; PK) yang seharusnya dapat diantisipasi oleh tenaga kesehatan pada saat memberikan dosis antibiotik. Kegagalan melakukan antisipasi dapat meningkatkan risiko terjadinya kegagalan untuk mencapai efek terapeutik serta meningkatkan risiko terjadinya reaksi obat yang tidak dikehendaki (ROTD). ${ }^{7,8}$

Beberapa bukti penelitian menunjukkan besarnya permasalahan terkait ketidaktepatan penggunaan antibiotik pada bayi dan anakanak. Sebuah penelitian yang dilakukan di Taiwan menunjukkan hasil bahwa penundaan penggunaan antibiotik yang tepat pada pasien dengan multiple drug resistant Acinetobacter baumanii menjadi salah satu faktor yang dapat meningkatkan risiko kematian bayi di NICU. ${ }^{9}$ Selain berdampak pada peningkatan risiko terjadinya kegagalan terapi, salah satu dampak yang perlu diwaspadai adalah potensi terjadinya resistensi ketika antibiotik yang diberikan tidak dapat mencapai kadar minimum untuk menghambat pertumbuhan atau membunuh bakteri. Fenomena resistensi antibiotik merupakan salah satu permasalahan yang banyak dialami di NICU. Sebuah studi yang dilakukan di India menunjukkan bahwa antibiotik yang pada umumnya merupakan terapi lini pertama pengobatan infeksi pada neonatus seperti ampisilin dan seftriakson memiliki sensitivitas yang buruk terhadap sebagian besar organisme penyebab infeksi, atau dengan kata lain telah diklasifikasikan resisten. ${ }^{10}$ Beberapa bukti penelitian lainnya yang dilakukan pada setting NICU juga menekankan ancaman permasalahan terkait dengan penurunan sensitivitas patogen terhadap antibiotik lini pertama. ${ }^{11,12}$

Dalam kurun waktu 10 tahun terakhir, tidak terdapat penelitian terpublikasi dengan setting NICU di Indonesia yang ditujukan untuk melihat profil ketepatan penggunaan antibiotik. Beberapa penelitian di Indonesia ditujukan untuk mengidentifikasi: 1) epidemiologi infeksi dan profil penggunaan antibiotik pada suatu diagnosis tertentu; 2) profil sensitivitas patogen terhadap antibiotik. ${ }^{13-16}$ Ketepatan penggunaan antibiotik pada pasien rawat inap NICU di Indonesia penting untuk diteliti khususnya di era implementasi Jaminan Kesehatan Nasional (JKN) untuk mengetahui ketercukupan dan ketepatan alokasi anggaran yang disediakan. Penelitian ini bertujuan untuk mengkaji profil, biaya, dan ketepatan penggunaan antibiotik pada pasien NICU di sebuah rumah sakit 
pemerintah di Surabaya.

\section{Metode}

Penelitian ini merupakan penelitian potong lintang yang dilakukan setelah mendapatkan izin pengambilan data dari rumah sakit dengan nomor surat 070/14640/436.7.8/2015. Rumah sakit tempat pengambilan data merupakan rumah sakit milik pemerintah yang menjadi salah satu rujukan penanganan pasien yang ditanggung oleh program Jaminan Kesehatan Nasional. Kriteria inklusi dalam penelitian ini adalah pasien NICU yang mendapat antibiotik selama periode November-Desember 2015.

Pengambilan data penelitian ini dilakukan melalui beberapa cara, antara lain: 1) mencatat data yang terdapat dalam catatan rekam medis; 2) melakukan pengamatan secara langsung terhadap pasien; dan 3) melakukan konfirmasi kepada tenaga kesehatan lain apabila terdapat data yang tidak dimengerti atau data tidak terbaca. Parameter yang didokumentasikan dan dianalisis pada penelitian ini antara lain: 1) karakteristik pasien (umur, jenis kelamin, lama perawatan pasien, diagnosis dokter, hasil pemeriksaan laboratorium dan pemeriksaan fisik, hasil kultur bakteri, hasil terapi setelah mendapatkan perawatan), 2) karakteristik antibiotik (golongan dan jenis, kombinasi, rute pemberian, dosis beserta frekuensi, lama pemberian per administrasi, durasi pemberian selama perawatan, pergantian dosis regimen antibiotik); 3) profil kompatibilitas sediaan intravena (iv); 4) proses pergantian terapi antibiotik; 5) biaya penggunaan antibiotik; serta 6) ketepatan penggunaan antibiotik. Data lalu dianalisis secara deskriptif dengan menggunakan nilai rata-rata/mean ( $\tilde{x})$ dan/ atau dengan menggunakan bentuk persentase.

Di dalam penelitian ini, diagnosis yang diberikan oleh dokter dibedakan menjadi tiga bagian, yaitu: 1) diagnosis masuk, 2) diagnosis kerja; serta 3) diagnosis keluar. Diagnosis masuk didefinisikan sebagai diagnosis yang diberikan oleh dokter saat pasien pertama kali masuk ruang NICU. Diagnosis kerja adalah diagnosis selama menjalani rawat inap yang diberikan oleh dokter setelah melihat berbagai hasil pemeriksaan penunjang, seperti pemeriksaan laboratorium dan pemeriksaan fisik. Diagnosis keluar merupakan diagnosis yang diberikan oleh dokter saat pasien keluar dari ruang NICU.

Analisis kompatibilitas dan inkompatibilitas dilakukan pada pencampuran antara sediaan antibiotik dengan antibiotik lain, antara sediaan antibiotik dengan obat lain, serta antara sediaan antibiotik dengan pelarut. Analisis yang telah dilakukan digolongkan ke dalam beberapa jenis hasil, antara lain yaitu kompatibel (K), inkompatibel (I), tidak terdapat informasi yang tersedia (no information; NI), serta tidak dapat diaplikasikan (not applicable; NA). Analisis dilakukan dengan menggunakan dua literatur sebagai acuan, yaitu: 1) Handbook on Injectable Drugs edisi 17 tahun 2013; ${ }^{17}$ dan 2) brosur sediaan antibiotik terkait. Pembuatan kesimpulannya antara lain sebagai berikut: 1) campuran dinyatakan kompatibel apabila pada buku referensi dan/atau brosur dari pabrik pembuat sediaan disimpulkan dengan jelas bahwa campuran tersebut $\mathrm{K}$; 2) campuran dinyatakan inkompatibel apabila pada buku referensi dan/atau brosur disimpulkan dengan jelas campuran tersebut ialah I; 3) campuran dinyatakan NI apabila pada buku referensi dan/atau brosur tidak ditemukan informasi mengenai profil kompatibilitas campuran tersebut; 4) campuran dinyatakan NA apabila pada buku referensi dan/atau brosur terdapat perbedaan informasi.

Proses pergantian terapi antibiotik pada penelitian ini digolongkan menjadi 3, yaitu: 1) proses eskalasi; 2) proses de-eskalasi; 3) proses pergantian rute dari rute intravena menjadi per oral (iv to oral). Proses eskalasi pada penelitian ini didefinisikan sebagai suatu proses penambahan antibiotik pada pasien yang telah mendapatkan antibiotik ataupun 
digantinya suatu antibiotik dengan antibiotik baru yang memiliki aktivitas antibakteri yang lebih luas (narrow spectrum menjadi broad spectrum). Suatu proses pergantian terapi disebut proses de-eskalasi apabila dilakukan beberapa hal sebagai berikut: 1) pergantian antibiotik dari antibiotik dengan aktivitas antibakteri luas ke sempit (broad spectrum ke narrow spectrum); 2) pengurangan jumlah antibiotik yang digunakan; 3 ) penurunan dosis antibiotik; 4) penurunan frekuensi antibiotik; dan 5) penghentian terapi antibiotik apabila tidak ditemukan adanya infeksi. Penggunaan kombinasi antibiotik golongan beta laktam dengan beta laktamase tidak diklasifikasikan sebagai bentuk kombinasi pada penelitian ini. Perubahan terapi antibiotik yang dilakukan sebagai bentuk transisi, yaitu terjadi hanya pada 1 hari pemberian, tidak diklasifikasikan sebagai eskalasi atau de-eskalasi.

Biaya yang dihitung pada penelitian ini adalah biaya penggunaan antibiotik selama pasien menjalani rawat inap. Biaya jasa dokter, penggunaan obat lainnya, serta pemeriksaan laboratorium tidak dihitung dalam penelitian ini. Perspektif pasien digunakan sebagai dasar dari penghitungan biaya pada penelitian ini dan data billing yang dikeluarkan oleh pihak rumah sakit kepada pasien digunakan sebagai sumber utama analisis biaya. Tidak dilakukan penyesuaian menggunakan laju inflasi pada penelitian ini karena data biaya dan analisis dilakukan pada tahun yang sama.

Analisis ketepatan penggunaan antibiotik pada penelitian ini dilakukan dengan cara membandingkan regimen terapi pasien terhadap pedoman terapi Infectious Disease Society of America (IDSA) terbaru. Literatur Pediatric \& Neonatal Dosage Handbook edisi 2018 digunakan sebagai acuan pendukung apabila tidak didapatkan informasi yang diperlukan di literatur acuan yang utama, seperti dosis. Terdapat tiga klasifikasi ketepatan penggunaan antibiotik pada penelitian ini, yaitu tepat seluruhnya, tepat sebagian, dan tidak tepat sama sekali. Suatu pemberian antibiotik disebut sebagai tepat seluruhnya apabila jenis, dosis, dan frekuensi pemberian antibiotik tersebut tepat seluruhnya. ${ }^{19}$ Pemberian antibiotik disebut sebagai tepat sebagian bila diberikan jenis antibiotik yang tepat namun dengan dosis atau frekuensi yang tidak tepat, sedangkan apabila pemberian jenis antibiotik tidak tepat maka pemberian antibiotik dianggap tidak tepat tanpa harus memperhatikan dosis dan frekuensi yang diberikan. Analisis kesesuaian antibiotik ini dilakukan pada pasien dengan diagnosis kerja infeksi saja.

\section{Hasil}

Total terdapat 32 pasien NICU selama periode pengambilan data pasien yang dilibatkan dalam penelitian ini (Tabel 1). Uji kultur mikroba dan sensitivitas tidak dilakukan pada pasien NICU dalam penelitian ini. Diagnosis kerja dan diagnosis keluar pasien NICU memiliki hasil yang sama. Terdapat 13 pasien $(40,63 \%)$ dari total 32 pasien yang mendapatkan diagnosis infeksi. Dengan kata lain, 19 pasien $(59,37 \%)$ lainnya tidak diketahui informasi diagnosis infeksi baik pada diagnosis masuk maupun kerja. Akan tetapi, pada 19 pasien tanpa disertai informasi diagnosis terkait infeksi tersebut memiliki satu atau beberapa tanda infeksi seperti peningkatan nilai white blood cell (WBC), C-reactive protein (CRP), suhu badan, denyut nadi, dan/atau laju nafas. Di antara 13 pasien dengan diagnosis infeksi, hanya 11 pasien $(84,62 \%)$ yang mendapatkan diagnosis masuk infeksi sedangkan 2 pasien $(15,38 \%)$ sisanya masuk ruang NICU tanpa diagnosis masuk infeksi. Detail diagnosis pasien dijabarkan pada Gambar 1.

Antibiotik yang digunakan pada penelitian ini tidak hanya antibiotik tunggal, melainkan juga antibiotik kombinasi. Terdapat 25 kali penggunaan antibiotik tunggal dan 14 kali penggunaan antibiotik kombinasi, dan 1 orang pasien dapat mendapatkan lebih dari 1 
Tabel 1 Data Karakteristik Pasien yang Mendapatkan Antibiotik di Ruang NICU

\begin{tabular}{lcr}
\hline \multicolumn{1}{c}{ Karakteristik Pasien } & Nilai & Persentase (\%) \\
\hline Usia Pasien (mean \pm SD, dalam satuan hari) & $0,78 \pm 2,38$ & - \\
Jenis Kelamin & Min-maks: $0-12$ & 71,88 \\
Laki-laki & 23 & 28,12 \\
Perempuan & 9 & $\mathbf{1 0 0 , 0 0}$ \\
Total & $\mathbf{3 2}$ & - \\
Lama Perawatan Pasien (mean \pm SD, dalam satuan hari) & $11,44 \pm 8,94$ & \\
& Min-maks: $2-33$ & 87,50 \\
Hasil Terapi Pasien & & 0,00 \\
Membaik & 28 & 6,25 \\
Memburuk & 0 & 6,25 \\
Meninggal & 2 & $\mathbf{1 0 0 , 0 0}$ \\
Dirujuk & 2 & $\mathbf{3 2}$ \\
Total & & \\
\hline
\end{tabular}

Keterangan: Min=minimal; Maks=maksimal; Penghitungan persentase dilakukan dengan rumus sebagai berikut:

$\%$ nilai=jumlah nilai pasien pada tiap karakteristik dibagi jumlah total pasien $\mathrm{x} 100 \%$

jenis penggunaan antibiotik tunggal maupun kombinasi. Jenis dan golongan dari antibiotik ditampilkan pada Tabel 2. Profil lengkap dosis dan frekuensi penggunaan untuk masingmasing antibiotik akan dijabarkan pada Tabel 3. Rata-rata dari durasi penggunaan antibiotik adalah sebesar 5,08 $\pm 2,07$ hari dan seluruh antibiotik diberikan secara iv intermittent dengan lama pemberian selama 10-15 menit untuk tiap kali pemberian.

Total terdapat 47 campuran antara antibiotik dengan pelarut yang dianalisis dalam penelitian ini. Pelarut antibiotik yang digunakan dalam penelitian ini adalah aqua bidestilata yang kemudian diencerkan kembali dengan pelarut PZ (NaCL 0,9\%). Analisis kompatibilitas-

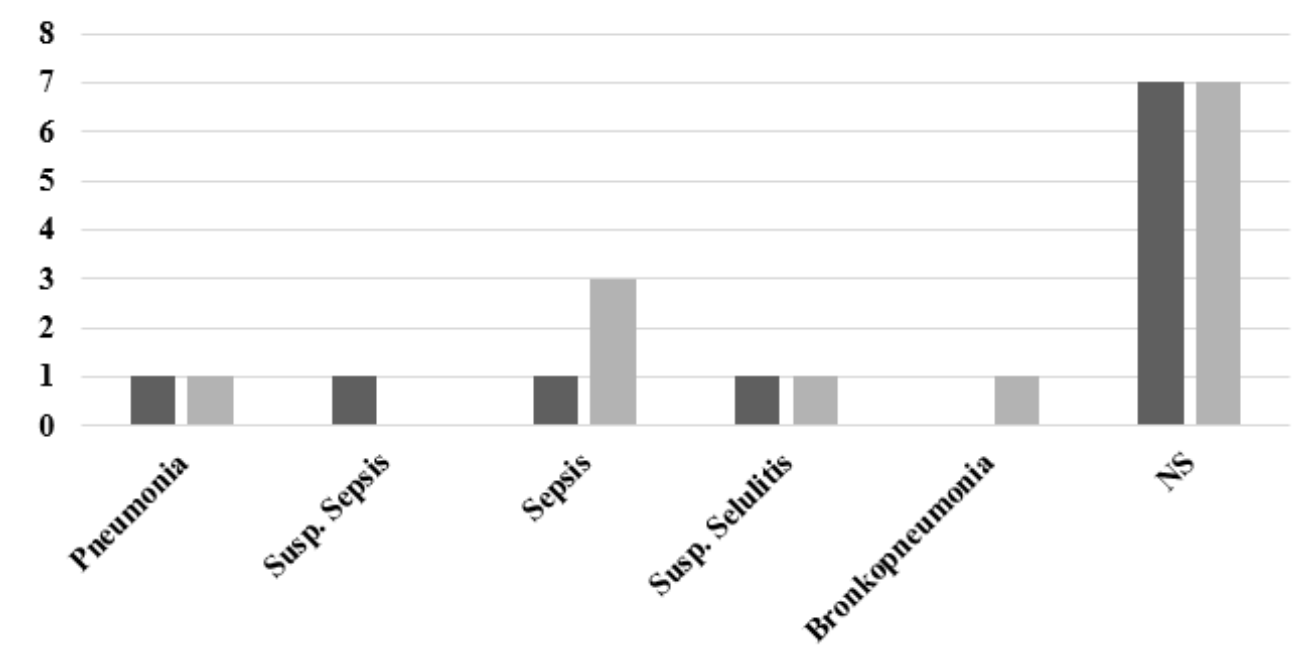

@Diagnosis Masuk $\backsim$ Diagnosis Kerja/Keluar

Gambar 1 Diagnosis Masuk dan Kerja/Keluar Pasien NICU dengan Diagnosis Infeksi

Keterangan: NS=Not specified (pada diagnosis dokter tertulis jelas infeksi atau risiko tinggi infeksi tanpa ada keterangan lebih detail terkait jenis infeksinya) 
inkompatibilitas sediaan antibiotik intravena dengan sediaan lainnya dijabarkan pada Tabel 4. Pada penelitian ini ditemukan campuran antibiotik dengan pelarut tanpa informasi (no information) ketercampuran yaitu sebanyak 6 untuk pelarut PZ dan 47 untuk pelarut aqua bidestilata.

Proses pergantian terapi terjadi pada 6 pasien dengan total terdapat 9 kali proses pergantian terapi. Detail dari proses pergantian terapi dapat dilihat pada Tabel 5. Proses penggantian terapi antibiotik dari iv ke oral tidak ditemukan dalam penelitian ini.

Rata-rata biaya yang dikeluarkan pasien untuk penggunaan antibiotik pada penelitian ini sebesar Rp265.252,00 dengan standar deviasi (SD) sebesar Rp481.535,00. Biaya terbesar yang dikeluarkan sebesar Rp2.091.590,00 sedangkan biaya yang terkecil yaitu sebesar Rp16.100,00. Pasien dengan biaya terbesar menggunakan sebanyak tiga jenis antibiotik selama perawatannya yaitu ampisilin, gentamisin dan meropenem yang seluruhnya merupakan antibiotik generik. Ampisilin digunakan selama 5 hari, gentamisin digunakan selama 3 hari dan meropenem digunakan selama 17 hari.

Analisis kesesuaian antibiotik dilakukan pada 13 pasien yang mendapatkan diagnosis infeksi saja. Hasilnya, hanya terdapat 2 pasien (15,38\%) yang diklasifikasikan sebagai pasien dengan terapi antibiotik yang tepat seluruhnya. Detail dari analisis kesesuaian penggunaan antibiotik dijabarkan pada Tabel 6. Terdapat 1 orang pasien yang mendapatkan antibiotik yang tidak tepat sama sekali.

\section{Pembahasan}

Terdapat 5 jenis antibiotik yang digunakan di NICU pada penelitian ini, yaitu ampisilin, gentamisin, meropenem, sefotaksim, dan kloksasilin, namun penggunaan terbanyak

Tabel 2 Data Karakteristik Penggunaan Antibiotik Berdasarkan Anatomical Therapeutics Chemical (ATC) Classification of World Health Organization (WHO) (Revisi 2015)

\begin{tabular}{lcc}
\hline \multicolumn{1}{c}{ Antibiotik } & Penggunaan & Persentase (\%) \\
\hline Antibiotik Tunggal & & \\
1. Penisilin & & \\
$\quad$ Extended Spectrum Penicillin & 15 & 60,00 \\
$\quad$ Ampisilin & & \\
2. Sefalosporin & & \\
$\quad$ Sefalosporin generasi ketiga & 4 & 16,00 \\
$\quad$ Sefotaksim & & \\
3. Karbapenem & 6 & 24,00 \\
$\quad$ Meropenem & $\mathbf{2 5}$ & $\mathbf{1 0 0 , 0 0}$ \\
$\quad$ Total & & \\
Antibiotik Kombinasi & & \\
1. Berdasarkan golongan antibiotik & 1 & 7,14 \\
$\quad$ Penisilin \& penisilin & 10 & 71,43 \\
$\quad$ Penisilin \& aminoglikosida & 1 & 7,14 \\
$\quad$ Penisilin \& sefalosporin generasi 3 & 2 & 14,29 \\
$\quad$ Penisilin \& aminoglikosida \& sefalosporin generasi 3 & $\mathbf{1 4}$ & $\mathbf{1 0 0 , 0 0}$ \\
$\quad$ Total & & \\
2. Berdasarkan jenis antibiotik & 1 & 7,14 \\
$\quad$ Ampisilin \& kloksasilin & 10 & 7,14 \\
$\quad$ Ampisilin \& gentamisin & 1 & 14,29 \\
Ampisilin \& sefotaksim & 2 & $\mathbf{1 0 0 , 0 0}$ \\
$\quad$ Ampisilin \& gentamisin \& sefotaksim & $\mathbf{1 4}$ & \\
$\quad$ Total & & \\
\hline
\end{tabular}


Tabel 3 Data Dosis Antibiotik dan Frekuensi Pemberian pada Pasien NICU

\begin{tabular}{|c|c|c|c|}
\hline Antibiotik & Dosis (mg) / Kali Pemberian & Frekuensi Pemberian & Jumlah Pasien (n) \\
\hline Ampisilin & $\begin{array}{l}\text { 1. } 75 \\
\text { 2. } 100 \\
\text { 3. } 125 \\
\text { 4. } 150 \\
\text { 5. } 175 \\
\text { 6. } 200 \\
\text { 7. } 250 \\
\text { Mean =136,54; Min-Max }=75-250\end{array}$ & $\begin{array}{l}2 \mathrm{x} / \text { hari } \\
2 \mathrm{x} / \text { hari } \\
2 \mathrm{x} / \text { hari } \\
2 \mathrm{x} / \text { hari } \\
2 \mathrm{x} / \text { hari } \\
2 \mathrm{x} / \text { hari } \\
2 \mathrm{x} / \text { hari }\end{array}$ & $\begin{array}{l}1 \\
6 \\
7 \\
8 \\
2 \\
1 \\
1\end{array}$ \\
\hline Sefotaksim & $\begin{array}{l}\text { 1. } 100 \\
\text { 2. } 125 \\
\text { 3. } 175 \\
\text { 4. } 250 \\
\text { Mean =162,5; Min-Max }=100-250\end{array}$ & $\begin{array}{l}2 \mathrm{x} / \text { hari } \\
2 \mathrm{x} / \text { hari } \\
2 \mathrm{x} / \text { hari } \\
2 \mathrm{x} / \text { hari }\end{array}$ & $\begin{array}{l}1 \\
1 \\
1 \\
1\end{array}$ \\
\hline Kloksasilin & $\begin{array}{l}1.75 \\
\text { Mean }=75\end{array}$ & $2 \mathrm{x} /$ hari & 1 \\
\hline Gentamisin & $\begin{array}{l}\text { 1. } 10 \\
\text { 2. } 12 \\
\text { 3. } 15 \\
\text { 4. } 20 \\
\text { Mean =13,2; Min-Max =10-20 }\end{array}$ & $\begin{array}{l}1 \mathrm{x} / \text { hari } \\
1 \mathrm{x} / \text { hari } \\
1 \mathrm{x} / \text { hari } \\
1 \mathrm{x} / \text { hari }\end{array}$ & $\begin{array}{l}4 \\
1 \\
4 \\
1\end{array}$ \\
\hline Meropenem & $\begin{array}{l}\text { 1. } 20 \\
\text { 2. } 35-25 \\
\text { 3. } 50 \\
\text { 4. } 100 \\
\text { Mean = 42,86; Min-Max =20-100 }\end{array}$ & $\begin{array}{l}3 \mathrm{x} / \text { hari } \\
3 \mathrm{x} / \text { hari } \\
3 \mathrm{x} / \text { hari } \\
3 \mathrm{x} / \text { hari }\end{array}$ & $\begin{array}{l}2 \\
1 \\
2 \\
1\end{array}$ \\
\hline
\end{tabular}

Keterangan: $\max =$ nilai terbesar; min=nilai terkecil; $\mathrm{n}=$ jumlah pasien yang menerima terapi antibiotik dengan dosis tersebut

yaitu jenis ampisilin, sefotaksim, dan gentamisin. Tingginya frekuensi penggunaan ketiga jenis antibiotik tersebut dapat dipahami dengan mempertimbangkan luasnya spektrum aktivitas antibiotik tersebut. Penggunaan dari antibiotik spektrum luas pada terapi empiris dilakukan sebab pada saat tersebut belum diketahui secara pasti patogen penyebab infeksi.

Profil penggunaan antibiotik pada hasil penelitian ini serupa dengan beberapa penelitian terpublikasi dari negara lain. Penelitian yang dilakukan di negara Amerika Serikat, Kanada dan Arab Saudi, menunjukkan bahwa terdapat tiga jenis obat yang paling sering digunakan di ruang NICU, dan dua di antaranya adalah antibiotik yaitu ampisilin dan gentamisin yang diberikan pada 1.691 bayi dan 1,667 bayi, secara berturut-turut. ${ }^{20}$ Hasil dari sebuah kajian sistematis yang dilakukan dengan memanfaatkan sebanyak empat buah database

Tabel 4 Data Kompatibilitas dan Inkompatibilitas Antibiotik dengan Pelarut pada Ruang NICU

\begin{tabular}{|c|c|c|}
\hline \multirow{2}{*}{ Hasil Analisis } & \multicolumn{2}{|c|}{ Pelarut } \\
\hline & PZ (NaCl $0,9 \%)$ & Aqua Bidestilata \\
\hline Kompatibel & $41(87,23)$ & $0(0,00)$ \\
\hline Inkompatibel & $0(0,00)$ & $0(0,00)$ \\
\hline No Information & $6(12,77)$ & $47(100,00)$ \\
\hline Not Applicable & $0(0,00)$ & $0(0,00)$ \\
\hline Total & $47(100,0)$ & $47(100,00)$ \\
\hline
\end{tabular}


Tabel 5 Data Proses Pergantian Terapi

\begin{tabular}{lcr}
\hline Proses pergantian & Nilai & Persentase (\%) \\
\hline Proses eskalasi & 2 & 22,22 \\
Proses de-eskalasi & 4 & 44,44 \\
Proses pergantian terapi dari rute IV ke oral & 0 & 0,00 \\
Proses transisi & 3 & 33,33 \\
Total & $\mathbf{9}$ & $\mathbf{1 0 0 , 0 0}$ \\
\hline
\end{tabular}

Keterangan: IV: intravena; penghitungan persentase dilakukan dengan rumus sebagai berikut:

$\%$ nilai $=$ jumlah proses pergantian terapi antibiotik dibagi total proses pergantian terapi antibiotik ( 9 proses) $\times 100 \%$

juga menegaskan bahwa antibiotik ampisilin dan gentamisin merupakan antibiotik yang paling sering diresepkan di ruang NICU. ${ }^{21}$ Pada dasarnya, meropenem juga memiliki spektrum aktivitas yang luas, namun tidak banyaknya penggunaan meropenem di dalam penelitian ini dapat disebabkan oleh adanya batasan penggunaan meropenem yang terdapat pada Formularium Nasional (Fornas). ${ }^{22}$ Seiring dengan minimnya frekuensi dari penggunaan meropenem diharapkan dapat berakibat pada penurunan dari temuan patogen yang resisten terhadap golongan karbapenem yang dalam beberapa tahun terakhir dilaporkan sebagai suatu ancaman dalam dunia kesehatan global termasuk di ruang ICU untuk anak. Sebuah penelitian yang dilakukan di 6 Pediatric ICU di negara Vietnam menunjukkan betapa banyaknya temuan berbagai Carbapenem resistant pathogen. Hasil dari uji mikrobiologi menunjukkan isolat Klebsiella pneumonia, Pseudomonas aeruginosa, Acinetobacter baumanii yaitu sebanyak $55 \%$, $71 \%$, dan $65 \%$, secara berturut-turut, resisten terhadap antibiotik golongan karbapenem..$^{23}$ Munculnya resistensi terhadap golongan karbapenem menyebabkan semakin terbatasnya pilihan terapi yang dimiliki pasien dan beberapa di antaranya memiliki harga yang relatif mahal seperti tigecycline dan doripenem..$^{24-26}$

Tingginya penggunaan antibiotik dengan spektrum luas, walaupun sangat diperlukan, dapat memiliki dampak pada munculnya kasus infeksi oleh bakteri dengan extended spectrum beta-lactamase (ESBL) sebuah enzim yang dapat memotong cincin beta-laktam pada hampir seluruh antibiotik golongan betalaktam. ${ }^{27-29}$ Selain memiliki dampak terhadap

Tabel 6 Data Analisis Kesesuaian Penggunaan Antibiotik Pasien NICU

\begin{tabular}{lcc}
\hline \multicolumn{1}{c}{ Kategori } & Pasien (orang) & Persentase (\%) \\
\hline Seluruh terapi AB tepat & 2 & 15,38 \\
Sebagian terapi AB tepat & & 53,86 \\
1. Frekuensi tidak tepat & & 7,69 \\
2. Dosis dan frekuensi tidak tepat ${ }^{\mathrm{b}}$ & 1 & 15,38 \\
3. Tidak tepat dengan catatan & \\
Terapi AB tidak tepat $^{\mathrm{d}}$ & 2 & 7,69 \\
Total & 1 & $\mathbf{1 0 0 , 0 0}$
\end{tabular}

Keterangan: $\mathrm{AB}=$ antibiotik; NICU=Neonatal Intensive Care Unit; penghitungan persentase dilakukan dengan rumus sebagai berikut: jumlah pasien dalam suatu hasil analisis kesesuaian dibagi jumlah total pasien dengan diagnosis infeksi (13 pasien) $\mathrm{x}$ $100 \%$; untuk pasien yang mengalami perubahan diagnosis (pasien no. 4), penggunaan antibiotik dianggap tidak tepat apabila ada ketidaktepatan pada salah satu diagnosis.

aPenggunaan ampisilin hanya $2 \mathrm{x} /$ hari $(\mathrm{n}=5)$; penggunaan ampisilin dan sefotaksim hanya $2 \mathrm{x} / \mathrm{hari}(\mathrm{n}=1)$; pasien dengan diagnosis sepsis hanya diberikan ampisilin dan diberikan hanya $2 \mathrm{x} / \mathrm{hari}(\mathrm{n}=1)$; ${ }^{\mathrm{b}}$ Dosis meropenem kurang dan frekuensi ampisilin hanya $2 \mathrm{x} /$ hari pada 1 orang pasien; 'Satu pasien diberikan jenis antibiotik yang melebihi yang dibutuhkan dan 1 pasien diberikan frekuensi anitibiotik yang melebihi yang diperlukan; ${ }^{\mathrm{d} D i a g n o s i s ~ s e p s i s ~ n e o n a t u s ~ d i b e r i k a n ~ k o m b i n a s i ~ a m p i s i l i n ~(f r e k u e n s i ~}$ ampisilin kurang, hanya 2x/hari) dan kloksasilin. 
munculnya ESBL, pemberian dari antibiotik dengan spektrum luas yang tidak bertanggung jawab dapat menimbulkan risiko terjadinya supra infeksi oleh Clostridium difficile..$^{30-32}$ Dengan mempertimbangkan besarnya risiko adanya infeksi ESBL dan Clostridium difficile, diharapkan penggunaan antibiotik spektrum luas dapat diubah menjadi antibiotik dengan spektrum yang lebih sempit sesuai dengan penyebab infeksi setiap pasien. Sayangnya, pemeriksaan kultur bakteri tidak ditemukan pada penelitian ini. Minimnya pemeriksaan kultur bakteri tidak hanya ditemukan dalam penelitian ini, akan tetapi juga pada beberapa penelitian lain di Indonesia. ${ }^{33-35}$ Salah satu pertimbangan utama tidak dilakukannya pemeriksaan kultur bakteri adalah biaya dan lamanya waktu tunggu untuk mendapatkan hasil kultur. Oleh karena itu, sangat diharapkan institusi pendidikan tinggi di Indonesia dengan didukung oleh pemerintah Indonesia dapat mengupayakan tersedianya alat yang dapat mengidentifikasi patogen penyebab infeksi secepat dan semurah mungkin.

Proses pergantian terapi pada penelitian ini yang paling banyak ditemukan adalah praktik de-eskalasi antibiotik. Praktik de-eskalasi antibiotik merupakan salah satu strategi dalam mengurangi penggunaan antibiotik spektrum luas yang memiliki dampak pada penurunan angka kejadian infeksi oleh multiple drug resistance (MDR) pathogens. ${ }^{36}$ Implementasi de-eskalasi juga ditemukan dalam penelitian terpublikasi lain, dan hasilnya menunjukkan bahwa implementasi intervensi pengubahan terapi antibiotik yang salah satunya berupa de-eskalasi tidak berdampak buruk terhadap pasien. ${ }^{37}$ Walaupun demikian, praktik dari de-eskalasi pada pasien bayi perlu mendapat perhatian dan pemantauan yang serius dengan mempertimbangkan belum sempurnanya sistem kekebalan pada tubuh bayi. Sebelum diputuskan untuk melakukan de-eskalasi, perlu dipertimbangkan keseimbangan antara dampak positif mengurangi risiko ROTD pada bayi serta upaya meminimalkan potensi terjadinya resistensi dan risiko kegagalan mencapai efektivitas pada bayi.

Pada penelitian ini, hanya ditemukan dua pasien yang tepat seluruh kriteria pemberian antibiotik dan terdapat satu orang pasien yang tidak tepat sama sekali. Mayoritas dari pasien dikategorikan mendapatkan terapi antibiotik yang sebagian tepat. Ketidaktepatan paling banyak ditemukan pada frekuensi pemberian antibiotik. Antibiotik yang masuk golongan $\beta$-lactam dalam penelitian ini, yakni ampisilin dan sefotaksim, berapapun dosisnya selalu diberikan dengan frekuensi dua kali per hari. Antibiotik golongan $\beta$-lactam merupakan golongan antibiotik time-dependent, yang berarti bahwa kemampuan membunuh bakteri dari golongan obat ini sangat ditentukan oleh lama kadar antibiotik berada di atas nilai kadar minimum yang dibutuhkan untuk menghambat pertumbuhan bakteri (minimum inhibitory concentration; MIC). ${ }^{38,39}$ Target dari terapi antibiotik time-dependent yaitu $\mathrm{T}_{>\mathrm{MIC}}$ yang berarti durasi waktu kadar antibiotik berada diatas nilai MIC diupayakan harus selama mungkin. Semakin lama kadar dari antibiotik golongan $\beta$-lactam berada di atas nilai MIC, maka semakin besar efektivitas untuk membunuh patogen. Terdapat dua acara pemberian antibiotik golongan time-dependent untuk memaksimalkan ketercapaian target farmakokinetik-farmakodinamik; (pharmaco kinetic-pharmacodynamic, PK-PD), yakni pemberian harus sesering mungkin atau menggunakan metode continuous infusion. ${ }^{40}$ Frekuensi pemberian ampisilin dan sefotaksim sebanyak dua kali sudah tepat hanya untuk bayi yang masih berusia $<1$ minggu.$^{18,41}$ Pada penelitian ini, terdapat bayi dengan usia lebih dari 1 minggu sehingga seharusnya diberikan dengan frekuensi 3 kali per hari atau setiap 8 jam. Bahkan, pada bayi yang berusia lebih dari 4 minggu, disarankan frekuensi pemberian kedua jenis antibiotik tersebut setiap 6 jam. ${ }^{18,41}$

Semua pemberian gentamisin di NICU 
dilakukan/diberikan 1 kali sehari atau secara once daily dosing regimen (OD). Berdasarkan referensi, pemberian gentamisin dianjurkan untuk diberikan satu kali sehari atau once dose daily. ${ }^{42}$ Pemberian dosis satu kali per hari pada antibiotik gentamisin dapat diterapkan dengan mempertimbangkan karakteristik antibiotik tersebut yang berupa concentration-dependent antibiotic. Antibiotik dengan karakteristik tersebut mempunyai aktivitas optimal dalam menghambat pertumbuhan atau membunuh bakteri yang sangat ditentukan oleh adanya ketercapaian konsentrasi maksimum $\left(\mathrm{C}_{\max }\right)$ dalam darah. Salah satu target terapi PK-PD yang merepresentasikan keberhasilan terapi secara klinis dan mikrobiologis gentamisin adalah rasio antara konsentrasi maksimum dibandingkan dengan MIC, atau disingkat $\mathrm{C}_{\text {max }} / \mathrm{MIC} .^{43,44}$ Namun demikian, pemberian dari gentamisin secara OD perlu diwaspadai dengan mempertimbangkan indeks terapi yang relatif sempit dan potensi menimbulkan nefrotoksisitas dan ototoksisitas seperti pada antibiotik golongan amynoglicosides lainnya. ${ }^{45,46}$ Oleh karena itu, pemantauan kadar gentamisin di dalam darah sangat diperlukan untuk mengoptimalkan ketercapaian efek terapeutik dan meminimalkan risiko terjadi reaksi obat yang tidak dikehendaki.

Kombinasi yang yang paling banyak digunakan di ruang NICU adalah kombinasi ampisilin dan gentamisin yang digunakan sebanyak 10 kali. Penggunaan kombinasi ini dilakukan dengan mempertimbangkan efek sinergis dari keduanya di dalam menghambat bakteri seperti Streptococcus, Enterococci, Listeria monocyogenes, dan beberapa jenis Enterobacteriaceae, seperti Entercobacter spp., Proteus spp., Escherichia coli. Selain keefektifannya, penggunaan dari kombinasi ampisilin dan gentamisin juga banyak terjadi sebab kombinasi ini mudah didapatkan dan harganya terjangkau sehingga cocok digunakan pada negara-negara berkembang. ${ }^{47}$

Pada penelitian ini sebagian besar terapi antibiotik diberikan kepada pasien dengan diagnosis yang tertulis di dalam catatan rekam medis tidak spesifik terkait infeksi sehingga penggunaan antibiotik pada pasien tersebut tidak dapat dinilai ketepatan penggunaannya berdasarkan pedoman terapi. Dengan kata lain, sebagian besar antibiotik pada penelitian ini diberikan dengan mempertimbangkan penyimpangan nilai hasil uji laboratorium, khususnya nilai CRP dan WBC. Penggunaan antibiotik pada bayi yang mempunyai nilai abnormal pada kedua parameter tersebut tidak dapat disalahkan. Pada suatu penelitian terpublikasi yang dilakukan secara retrospektif pada pasien infant dengan usia di bawah 90 hari menunjukkan bahwa penggunaan nilai CRP dapat menjadi salah satu prediktor di dalam mendiagnosis infeksi bakteri serius dan secara signifikan lebih baik digunakan sebagai diagnostic marker dibanding sebagai karakteristik klinis apabila dibanding dengan tes absolute neutrophil count (ANC) dan WBC. ${ }^{48}$ Pemantauan pemeriksaan fisik dan pemeriksaan laboratorium perlu dilakukan secara teratur dan berkesinambungan, serta penggunaan antibiotik sebaiknya dihentikan atau dilakukan de-eskalasi pemberian antibiotik apabila keadaan pasien sudah membaik. Penghentian penggunaan antibiotik tersebut perlu untuk dilakukan sebagai upaya untuk meminimalkan terjadinya reaksi obat yang tidak dikehendaki, meminimalkan timbulnya kasus resistensi patogen, dan untuk mencegah pembengkakan biaya pengobatan. Apabila tidak dihentikan sesegera mungkin, salah satu akibat atau konsekuensi yang langsung dapat dirasakan adalah tidak terkontrolnya pembiayaan antibiotik yang pada penelitian ini dapat mencapai Rp2.091.590,00.

\section{Simpulan}

Jenis antibiotik yang banyak digunakan di NICU pada penelitian ini adalah ampisilin, gentamisin, meropenem, sefotaksim, dan 
kloksasilin baik dalam bentuk tunggal atau kombinasi. Antibiotik di ruang NICU pada penelitian ini sebagian besar diberikan dengan berdasarkan penyimpangan nilai pemeriksaan laboratorium yang belum disertai dengan diagnosis pasti terkait jenis infeksi yang diderita. Sebagai konsekuensi dari hal ini, analisis ketepatan hanya dapat dilakukan pada 13 orang pasien dengan hasil kajian yang menyatakan sebagian besar pasien belum mendapatkan terapi tepat pada seluruh aspek penilaian yang meliputi jenis, dosis, frekuensi. Pemantauan terhadap kondisi klinis dan hasil pemeriksaan laboratorium perlu untuk diupayakan sesering mungkin dan secara berkesinambungan sebagai dasar untuk mencegah penggunaan antibiotik yang berlebihan.

\section{Pendanaan}

Penelitian ini dilakukan secara mandiri dan tidak didanai oleh sumber hibah manapun.

\section{Konflik Kepentingan}

Peneliti menyatakan tidak terdapat konflik kepentingan apapun pada penelitian ini.

\section{Daftar Pustaka}

1. Lanata CF, Fischer-Walker CL, Olascoaga AC, Torres CX, Aryee MJ, Black RE. Global causes of diarrheal disease mortality in children $<5$ years of age: A systematic review. PLoS One. 2013;8(9):e72788. doi: 10.1371/journal.pone.0072788

2. Liu L, Oza S, Hogan D, Perin J, Rudan I, Lawn JE, et al. Global, regional, and national causes of child mortality in 200013, with projections to inform post-2015 priorities: An updated systematic analysis. Lancet. 2015;385(9966):430-40. doi: 10.1 016/S0140-6736(14)61698-6

3. Alves JB, Gabani FL, Ferrari RAP, Tacla MTGM, Linck Júnior A. Neonatal sepsis: mortality in a municipality in southern Brazil, 2000 to 2013. Rev Paul Pediatr. 2018;36(2):132-40.

4. Levy ER, Swami S, Dubois SG, Wendt R, Banerjee R. Rates and appropriateness of antimicrobial prescribing at an academic children's hospital, 2007-2010. Infect Control Hosp Epidemiol. 2012;33(4):34653. doi: 10. 1086/664761.

5. Fernadez E, Perez R, Hernandez A, Tejada P, Arteta M, Tamos JT. Factors and mechanism for pharmacokinetic differences between pediatric population and adults. Pharmaceutics. 2011;3(1):53-72. doi: 10. 3390/pharmaceutics3010053.

6. $\mathrm{Ku}$ LC, Smith PB. Dosing in neonates: Special considerations in physiology and trial design. Pediatric Res. 2015;77(1-1): 2-9. doi: 10.1038/pr.2014.143.

7. Johnson JK, Laughon MM. Antimicrobial agent dosing in infants. Clin Ther. 2016; 38(9):1948-60. doi: 10.1016/j.clinthera.2 016.06.017.

8. Nunes BM, Xavier TC, Martins RR. Antimicrobial drug-related problems in a neonatal intensive care unit. Rev Bras Ter Intensiva. 2017;29(3):331-6. doi: 10.593 5/0103-507X.20170040.

9. Wei HM, Hsu YL, Lin HC, Hsieh TH, Yen TY, Lin HC, et al. Multidrug-resistant Acinetobacter baumanii infection among neonates in a neonatal intensive care unit at a medical center in central Taiwan. J Microbiol Immunol Infect. 2015;48(5): 531-9. doi: 10.1016/j.jmii.2014.08.025.

10. Verma P, Berwal PK, Nagaraj N, Swami S, Jivaji P, Narayan S. Neonatal sepsis: Epidemiology, clinical spectrum, recent antimicrobial agents, and their antibiotic susceptibility pattern. Int J Contemp Pediatr. 2015;2(3):176-80. doi: 10.18203/2349-3 291.ijcp20150523

11. Awad HA, Mohamed MH, Badran NF, Mohsen M, Abd-Elrhman AS. Multidrugresistant organisms in neonatal sepsis in 
two tertiary neonatal ICUs, Egypt. J Egypt Public Health Assoc. 2016;91(1):31-8.doi: 10.1097/01.EPX.0000482038.76692.3.

12. Shrestha S, Shrestha NC, Dongol Singh S, Shrestha RP, Kayestha S, Shrestha M, et al. Bacterial isolates and its antibiotic susceptibility pattern in NICU. Kathmandu Univ Med J. 2013;11(41):66-70.

13. Haryani S, Apriyanti YF. Evaluasi terapi obat pada pasien sepsis neonatal di ruang perinatologi RSUP Fatmawati JanuariFebruari tahun 2016. Fatmawati Hosp J. 2016;1:1-10.

14. Fernando L. Pola bakteri dan sensitivitas antibiotik di NICU Siloam Hospitals Lippo Village, 2013-2014. Cermin Dunia Kedokt. 2017;44(3):167-70.

15. Estiningsih D, Puspitasari I, Nuryastuti T. Identifikasi infeksi multidrug-resistant organisms (MDRO) pada pasien yang dirawat di bangsal neonatal intensive care unit (NICU) rumah sakit. J Manajemen Pelayanan Farmasi. 2016;6(3):243-8. doi: 10.22146/jmpf.351

16. Prithadewi AAA, Hasmono D, Sukrama DM, Artana WD. Bacterial and antibiotics sensitivity pattern in neonatal sepsis patients. Folia Medica Indones. 2015;51 (1):1-6.

17. Trissel LA. Handbook on injectable drugs, $17^{\text {th }}$ dition. Bethesda: American Society of Health-System Pharmacists; 2011.

18. Takemoto CK, Hodding JH, Kraus, DM. Pediatric \& neonatal dosage handbook, $20^{\text {th }}$ edition. Hudson, Ohio: Lexi-Comp, Inc; 2013.

19. Wattengel BA, Sellick JA, Skelly MK, Napierala R Jr, Schroeck J, Mergenhagen KA. Outpatient antimicrobial stewardship: Targets for community-acquired pneumonia. Clin Ther. 2019;41(3):466-76. doi: 10.1016 /j.clinthera.2019.01.007.

20. Kumar A, Zarychanski R, Light B, Parrillo J, Maki D, Simon D, et al. Early combination antibiotic therapy yields improved survival compared with monotherapy in septic shock: A propensity-matches analysis. Crit Care Med. 2010;38(9):1773-85. doi: 10.10 97/CCM. 0b013e3181eb3ccd.

21. Krzyżaniak N, Pawłowska I, Bajorek B. Review of drug utilization patterns in NICUs worldwide. J Clin Pharm Ther. 2016;41(6):612-20. doi: 10.1111/jcpt.12 440

22. Kementerian Kesehatan Republik Indonesia. Formularium Nasional 2017 [Diakses: 14 April 2018]. Tersedia dari: http://farmalkes. kemkes.go.id/2018/02/formularium-nasi onal-2017/\#.Wx4j70xu KUk.

23. Le NK, Hf W, Vu PD, Khu DT, Le HT, Hoang BT, et al. High prevalence of hospital acquired infections caused by gram-negative carbapenem resitant strains in Vietnamese pediatric ICUs: A multicentre point prevalence survey. Medicine. 2016;95(27):e4099. doi: 10.1097/MD.000 0000000004099.

24. Morrill HJ, Pogue JM, Kaye KS, LaPlante KL. Treatment options for carbapenem-resistant Enterobacteriaceae infections. Open Forum Infect Dis. 2015; 2(2):ofv050. doi: 10.1093/ofid/ofv050

25. Trecarichi EM, Tumbarello M. Therapeutic options for carbapenemresistant Enterobacteriaceae infections. Virulence. 2017;8(4):470-84. doi: 10.108 0/215 05594.2017.1292196.

26. Yamamoto M, Pop-Vicas AE. Treatment for infections with carbapenem-resistant Enterobacteriaceae: What options do we still have?. Crit Care. 2014;18(3):229. doi: 10.1186/cc13949.

27. Drawz SM, Bonomo RA. Three decades of $\beta$-lactamase inhibitors. Clin Microbiol Rev. 2010;23(1):160-201. doi: 10.1128/C MR.00037-09.

28. Bush K. Bench-to-bedside review: The role of $\beta$-lactamases in antibiotic-resistant gram-negative infections. Crit Care. 2010; 14(3):224. doi: 10.1186/cc8892. 
29. Somily AM, Alsubaie SS, BinSaeed AA, Torchyan AA, Alzamil FA, Al-Aska AI, et al. Extended-spectrum $\beta$-lactamaseproducing Klebsiella pneumoniae in the neonatal intensive care unit: Does vancomycin play a role?. Am J Infect Control. 2014;42(3):277-82.

30. Predrag S. Analysis of risk factors and clinical manifestations associated with Clostridium difficile disease in Serbian hospitalized patients. Braz J Microbiol. 2016;47(4):902-10. doi: 10.1016/j.bjm.2 016.07.011.

31. Guh AY, Adkins SH, Li Q, Bulens SN, Farley MM, Smith Z, et al. Risk factors for community-associated clostridium difficile infection in adults: A case-control study. Open Forum Infect Dis. 2017;4(4): ofx171. doi: 10.1093/ofid/ofx171.

32. Chalmers JD, Akram AR, Singanayagam A, Wilcox MH, Hill AT. Risk factors for Clostridium difficile infection in hospitalized patients with communityacquired pneumonia. J Infect. 2016;73(1): 45-53. doi: 10.1016/jjinf.2016.04.008

33. Trisnowati KE, Irawati S, Setiawan E. Kajian penggunaan antibiotik pada pasien diare akut di bangsal rawat inap anak. J Manajemen Pelayanan Farmasi. 2017:17(1):16-24. doi: 10.22146/jmpf.3 63

34. Halim SV, Yulia R, SetiawanE. Penggunaan antibakteri golongan Carbapenem pada pasien dewasa rawat inap sebuah rumah sakit swasta di Surabaya. Indones J Clin Pharm. 2017;6(4):290-4. doi: 10.15416/i jcp.2017.6.4.267

35. Hidayat F, Setiadi A, Setiawan E. Analisis penggunaan dan biaya antibiotik di ruang rawat intensif sebuah Rumah Sakit di Surabaya. Pharmaciana. 2017;7 (2):213-30. doi: 10.12928/pharmaciana.v $7 \mathrm{i} 2.6767$

36. Lew KY, Ng TM, Tan M, Tan SH, Lew EL, Ling LM, et al. Safety and clinical outcomes of carbapenem de-escalation as part of an antimicrobial stewardship programme in an ESBL-endemic setting. J Antimicrob Chemother. 2015; 70(4):1219 -25. doi: 10.1093/jac/dku479.

37. Haque A, Hussain K, Ibrahim R, Abbas Q, Ahmed SA, Jurair H, et al. Impact of pharmacist-led antibiotic stewardship program in a PICU of low/middle-income country. BMJ Open Qual. 2018;7(1):e00 0180. doi: 10.1136/bmjoq-2017-000180

38. MacGowan A. Revisiting beta-lactamsPK/PD improves dosing of old antibiotics. Curr Opin Pharmacol. 2011;11(5):470-6. doi: 10.1016/j.coph.2011.07.006.

39. Nielsen EI, Cars O, Friberg LE. Pharmacokinetic/Pharmacodynamic (PK/ PD) indices of antibiotics predicted by a semimechanistic PKPD model: A step toward model-based dose optimization. Antimicrob Agents Chemother. 2011;55 (10):4619-30. doi: 10.1128/AAC.0018211

40. Walker MC, Lam WM, Manasco KB. Continuous and extended infusions of $\beta$-lactam antibiotics in the pediatric population. Ann Pharmacother. 2012;46 (11):537-46. doi: 10.1345/aph.1R216.

41. Neonatal Formulary. Drug use in pregnancy and first year of life, $5^{\text {th }}$ edition. Singapore; Balckwell Publishing: 2007.

42. Abdel-Bari A, Mokhtar MS, Sabry NA, El-Shafi SA, Bazan NS. Once versus individualized multiple daily dosing of aminoglycoside in critcally ill patients. Saudi Pharm J. 2011;19(1):9-17. doi: 10. 1016/j.jsps.2010.11.001

43. Rao SC, Srinivasjois R, Moon K. One dose per day compared to multiple doses per day of gentamycin for treatment of suspected or proven sepsis neonates. Cochrane Database Syst Rev. 2016;(11):CD005091. doi: 10.1002/14651858.CD005091.pub4.

44. Darmstadt GL, Batra M, Zaidi AK. Parenteral antibiotics for the treatment 
of serious neonatal bacterila infection in developing country. Pediatr Infect Dis J. 2009;28(1):S37-42. doi: 10.1097/INF.0b $013 \mathrm{e} 31819588 \mathrm{c} 3$.

45. Huth ME, Ricci AJ, Cheng AG. Mechanisms of aminoglycoside ototoxicity and targets of hair cell protection. Int $\mathrm{J}$ Otolaryngol. 2011;2011: 937861. doi: 10. 1155/2011/937861.

46. Wargo KA, Edwards JD. Aminoglycosideinduced nephrotoxicity. J Pharm Pract. 2014;27(6):573-7. doi: 10.1177/0897190
014546836.

47. Furyk JS, Swan Q, Molyneux E. Systematic review: Neonatal meningitis in the developing world. Trop Med Int Health. 2011;16(6):672-9. doi: 10.1111/j. 1365-3156.2011.02750.x.

48. Nosrati A, Ben Tov A, Reif S. Diagnostic markers of serious bacterial infections in febrile infants younger than 90 days old. Pediatr Int. 2014;56(1):47-52. doi: 10.11 11/ped.12191. 